\title{
Lithic Variability and Techno-Economy of the Initial Upper Palaeolithic in the Levant
}

\author{
Dirk Leder \\ Institute of Prehistoric Archaeology, CRC 806 - "Our way to Europe”, University of Cologne, Cologne, Germany
}

\section{Email address:}

dleder1@uni-koeln.de

\section{To cite this article:}

Dirk Leder. Lithic Variability and Techno-Economy of the Initial Upper Palaeolithic in the Levant. International Journal of Archaeology. Vol. 6, No. 1, 2018, pp. 23-36. doi: 10.11648/j.ija.20180601.14

Received: May 18, 2018; Accepted: June 6, 2018; Published: June 29, 2018

\begin{abstract}
The Levant forms a geographic bridge between Africa and Eurasia, making it a focal point for research on past human dispersals. The Initial Upper Palaeolithic (IUP) of the Levant is commonly associated with Homo sapiens' dispersal from Africa to Eurasia, which is characterised by substantial changes in material culture when compared to the preceding Middle Palaeolithic. While many researchers have noticed considerable variability among these IUP lithic assemblages, a systematic evaluation is currently missing. The study presented here addresses this cavity by employing techno-typological data from relevant Levantine IUP assemblages. Statistical methods, namely principal component analysis (PCA) and linear discriminant analysis (LDA) allow structuring these assemblages into distinct groups. These groups are then reviewed against palaeogeographic data and techno-economic behaviour patterns. Results show that IUP assemblages in the Mediterranean zone are similar to each other in regards to techno-typology, palaeogeography and techno-economic behaviour, being indicative of residential base camps. Contrastingly, assemblages in the semi-arid zone are more variable in regards to techno-typology and techno-economy, indicating more specialised activities such as hunting/butchering, which is often combined with local raw material exploitation.
\end{abstract}

Keywords: Initial Upper Palaeolithic, Middle-Upper Palaeolithic Transition, Levant, Lithics, Techno-Economy, Technological Organization, Human-Environment Interactions

\section{Introduction}

The geographic position of the Levant, situated between Africa and Europe, has made it a focal point of discussion concerning the dispersal of Homo sapiens out of Africa during the Pleistocene [1-14]. While $H$. sapiens emerged in Africa some 300-200 ka BP ago, making their first appearance in the Levant between ca. 200-120 ka BP, settlement in that region is often considered discontinuous and a second, genetically distinct population is expected to have left Africa around 60-50 ka BP [15-17].

The discovery of a human skull cap from Manot Cave suggests $H$. sapiens' recurrence into the Levant by ca. $55 \mathrm{ka}$, which is in agreement with palaeogenetic models [18]. $H$. sapiens' recurrence during the late Middle Palaeolithic is succeeded by a change in lithic material culture along with indications of symbolic behaviour expressed in the form of shell beads $[19,20]$. These changes in material culture traditions are subsumed under the umbrella terms 'Middle-
Upper Palaeolithic transition' or 'Initial Upper Palaeolithic' (IUP). While the term transition implies continuation between Middle and Upper Palaeolithic, IUP implies a disentanglement from preceding traditions [4, 10]. As the question of continuity is currently unresolved for most of Eurasia, IUP is preferred here as a more neutral term.

Lithic assemblages assigned to the Levantine IUP were first recognised in Lebanon (Abou Halka, Antelias Cave, Ksar Akil,) and in Israel (Emireh Cave and El-Wad Cave) before WWII, and the differences between both regions were acknowledged early [21-29]. In addition, a number of sites have been excavated since WWII (Ansab 2, Boker Tachtit, Jerf Ajla Cave, Mughr el-Hamamah, Tor Sadaf, Üçağızli Cave, Raqefet Cave, Umm el Tlel and Wadi Aghar), and were placed within the IUP context, although they have been labelled variedly, e.g. transitional, IUP, Emiran, or intermediate (Table 1.; Figure 1; [30-37]). 
Table 1. IUP assemblages in the Levant mentioned in the text.

\begin{tabular}{llll}
\hline Site & IUP levels & Abbreviation & References \\
\hline Üçagizli Cave & I-F & Üç I-F & {$[30]$} \\
Umm el Tlel & IIbase, III2a & UM IIbase & {$[33-34]$} \\
Jerf Ajla Cave & B, C & JA B\&C & {$[31-32]$} \\
Abou Halka & IVf, IVe & AH IVf-IVe & {$[4,22,27,38]$} \\
Ksar Akil & XXV-XXI & KA XXV-XXI & {$[4,27-29,38]$} \\
Antelias Cave & V-VII & AN V-VII & {$[26]$, this study } \\
Tor Sadaf & A, B & TS A\&B & {$[35]$} \\
Boker Tachtit & $1-4$ & BT 1 & {$[35,39,40]$} \\
Ansab 2 & - & ANS2 & {$[37]$, this study } \\
\hline
\end{tabular}

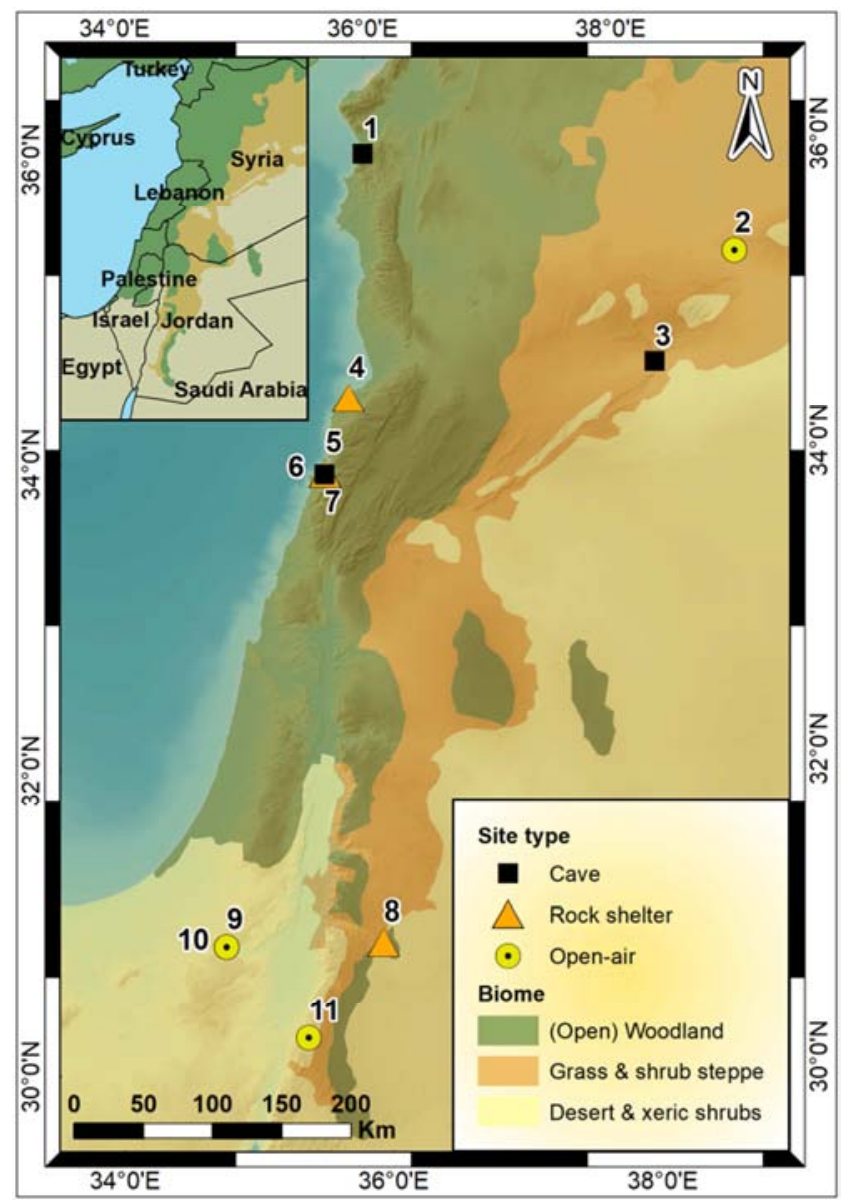

Figure 1. Sites and assemblages mentioned in the text. (1) Üçağızli Cave. (2) Umm el Tlel. (3) Jerf Ajla Cave. (4) Abou Halka. (5) Ksar Akil XXV-XXII. (6) Ksar Akil XXI. (7) Antelias Cave. (8) Tor Sadaf. (9) Boker Tachtit 1-3. (10) Boker Tachtit 4. (11) Ansab 2. Biomes are based on modern data changed after [42] since no biome data was available for MIS 3.

Dating efforts in recent years have shown that IUP assemblages were deposited broadly between Heinrich 4 and 5 , i.e. during $10-15 \mathrm{ka}$. Although various age estimates are under discussion, Boker Tachtit 1 would currently represent the oldest assemblage - presupposed that renewed dating can confirm the conventional $\mathrm{C}^{14}$ dates - and Umm el Tlel III2a would represent the youngest assemblage (Figure 2).
Charcoal from Boker Tachtit was dated by conventional radiocarbon dating, resulting in large standard deviations [36].

Based on dated sea shells, two age models exist for Ksar Akil with an age difference of some $2-3$ ka between them [20, 41]. Dated charcoal from Üçagizli shows a bimodal distribution resulting in a younger data set and an older one for the same layers. While the authors support the older results, more recent radiocarbon dating on sea shells coincide with the younger set $[30,41]$. Comparable issues concern the TL dates of Jerf Ajla, which also created two different age sets [32]. Only the older one would overlap with age estimates from the nearby Umm el Tlel site that yielded consistent age estimates generated by TL \& radiocarbon dating [33-34]. Accordingly, most IUP sites seem to date around 40-45 ka cal BP, with Boker Tachtit possibly being older and two or three sites being younger than $40 \mathrm{ka}$ cal BP.

Lithic assemblages of the Levantine IUP involve diverse blade production systems on a) hierarchically organised cores (along-axis cores/recurrent convergent Levallois cores) and b) volumetric cores (Figure 3 (1-7); [4, 38, 43, 44]). Tool kits consist of typical Upper Palaeolithic tool types such as endscrapers, burins, and truncations plus numerous edgeretouched pieces, and in some cases, chamfered pieces, Emireh points or Umm el Tlel points (Figure 3 (15-19)). The convergent blank, sometimes called elongated (non-) Levallois point, is mutual to all IUP assemblages and a function as hunting/cutting tools, analogues to Levallois points, is assumed (Figure 3 (8-9); [45]).

Considerable variability among the various IUP lithic assemblages has been acknowledged for some time, but a clear outline is still missing. Consequently, this paper aims to investigate the techno-typological variability of Levantine IUP assemblages in a systematic manner, and to test for consistency regarding palaeogeographic factors and technoeconomy.

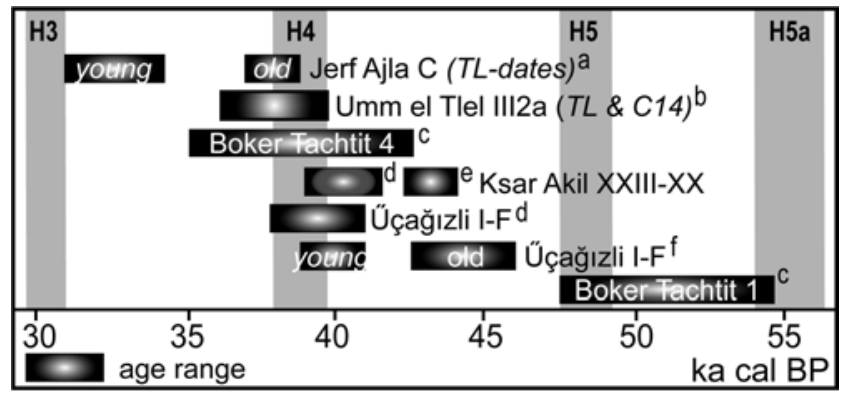

Figure 2. Radiometric age estimates of IUP sites in the Levant. All dates are radiocarbon dates unless indicated otherwise. Only calibrated dates are used, while estimates based on Bayesian modelling had to be excluded for reasons of better comparability. a: [32], b: [33-34], c: [36], d: [41], e: [20], $f:[30]$. 

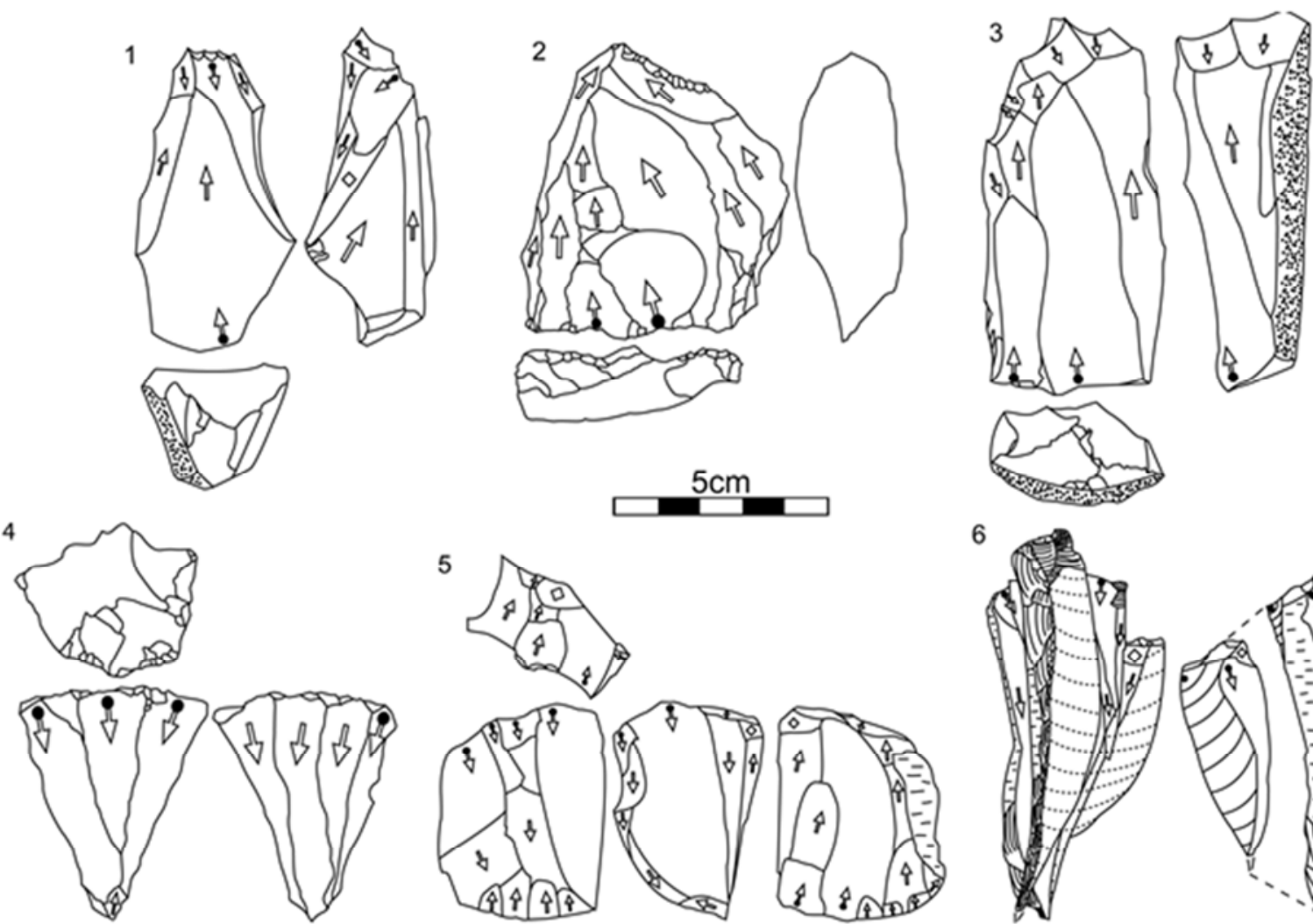

5
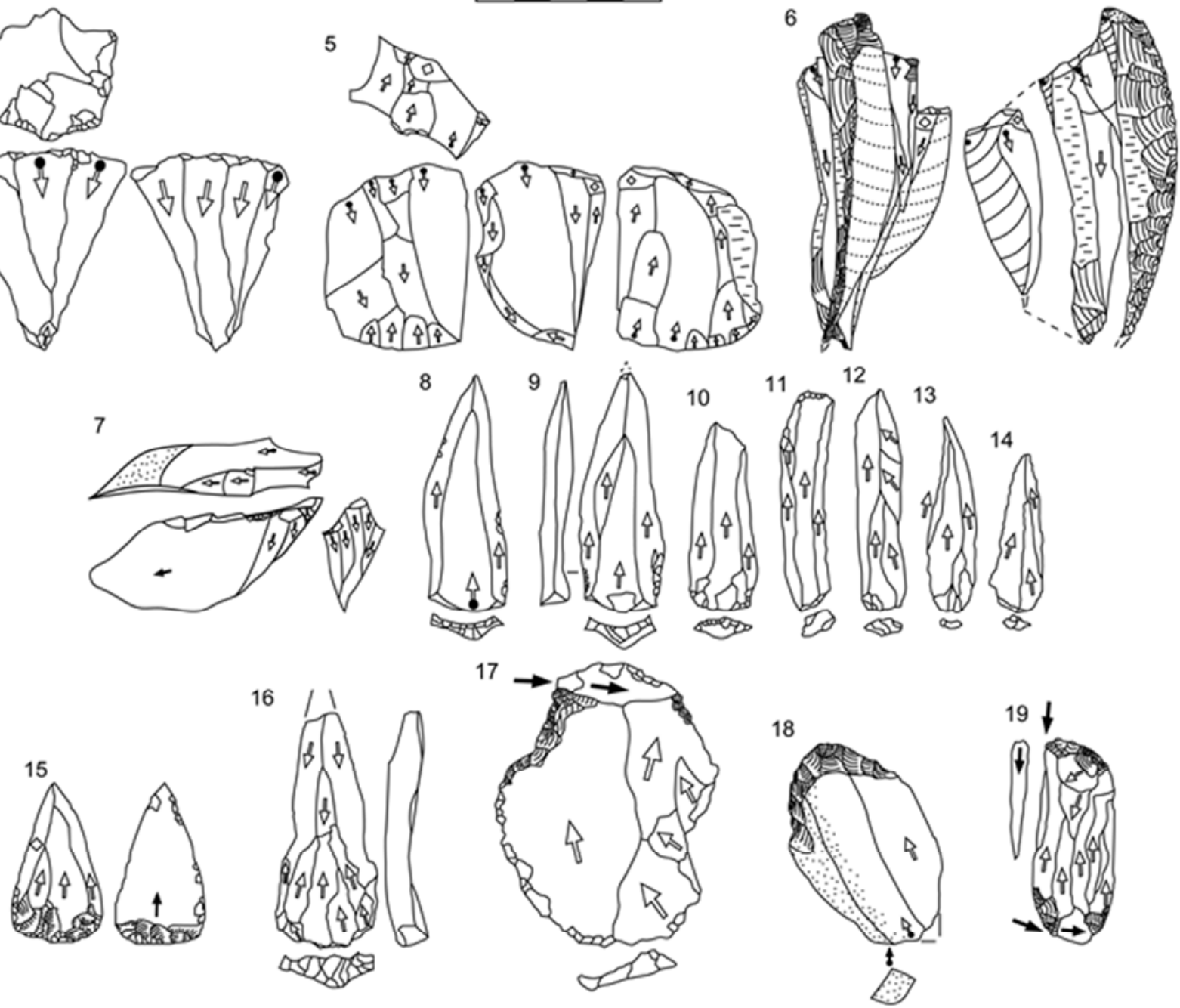

Figure 3. Typical lithic artefacts of the Levantine IUP. (1) preferential convergent along-axis core. (2) recurrent convergent along-axis core. (3) parallel along-axis core. (4-5) volumetric cores. (6) refitted blanks from blade core-on-flake. (7) bladelet-core-on-flake. (8-9) convergent blades. (10-11) blunt blades. (12-14) pointed blades. (15) Emireh point. (16) Umm el Tel point. (17) chanfrein. (18) endscraper; (19) burin-chanfrein. (1, 3, 8-9) redrawn from [26], (2, 4, 10-14, 17, 19) redrawn from [27], (5-7, 18) own work, (15) redrawn from [46], (16) redrawn from [39].

\section{Materials and Methods}

\subsection{Data Sources, Data Assessment and Data Processing}

Lithic assemblages and geographic information from Levantine IUP sites form the basis of this study (Tables 2-4).
While most of the data were extracted from published works (Üçagizli I-F, Umm el Tlel IIbase, Jerf Ajla B\&C, Abou Halka IVf/IVe, Ksar Akil XXV-XXI, Antelias VI-VII, Tor Sadaf A\&B, Boker Tachtit 1-4), some assemblages have been studied by the author (Table 1; Antelias V, Ksar Akil XXV, XXII, Abou Halka IVf, Ansab 2). Whenever 
technological differences were deemed minor in previous publications, assemblages from the same site have been combined in this study in order to simplify data handling and analysis.

Lithic assemblages from sites in Lower Galilee (Emireh Cave, El-Wad Cave and Raqefet caves) could not be included due to taphonomic issues, and published information from two other sites in Jordan - Mughr el-Hamamah and Wadi Aghar - are currently too preliminary to be considered [44, 47-50].

Not all publications provided information in the desired resolution due to different research goals and methods, and in some cases, different terminologies, making direct comparisons a challenge. Therefore, where quantitative data was not available, inferences were made from detailed written descriptions. Accordingly, when quantitative data were indeed provided in published works, data concerning the same variables were processed in the same way, so that inter-assemblage comparisons could be facilitated. In a few cases however, the selected variables could not be quantified at all. Additionally, some assemblages excavated before WWII did employ excavation standards that are not comparable to modern ones, impacting data quality, such as blank:tool ratios at Lebanese sites [23, 27].

Information obtained through these various sources were computed as standardised variables to make them serviceable in multivariate statistical analyses using the PAST 3.17 software [51]. Inter-assemblage variability was tested in three categories a) techno-typology, b) palaeogeography and c) techno-economy (Tables 2-4).

Principal component analysis (PCA) was individually performed on all three categories to identify major variables that underlie the observed inter-assemblage variability. PCA scores of the individual assemblages were then used to determine assemblage groups according to the aforementioned categories via linear discriminant analysis (LDA). Only groupings that resulted in $100 \%$ correct classifications when jackknifing was applied, were accepted. The consistency of these groups across the three predefined categories, i.e. techno-typology, paleogeography and techno-economy, was then assessed using linear regression analysis.

In respect to techno-economy data, tool kit richness and tool kit evenness have been calculated in order to estimate the range of activities performed with each tool kit (richness) and their functional specialisation (evenness). Menhinicks richness index was employed to calculate richness and the Shannon-Weaver index was employed to calculate evenness. Both account for tool kit size rather than simply providing tool type counts.

Table 2. Technological data of the various IUP sites employed in PCA \& LDA.

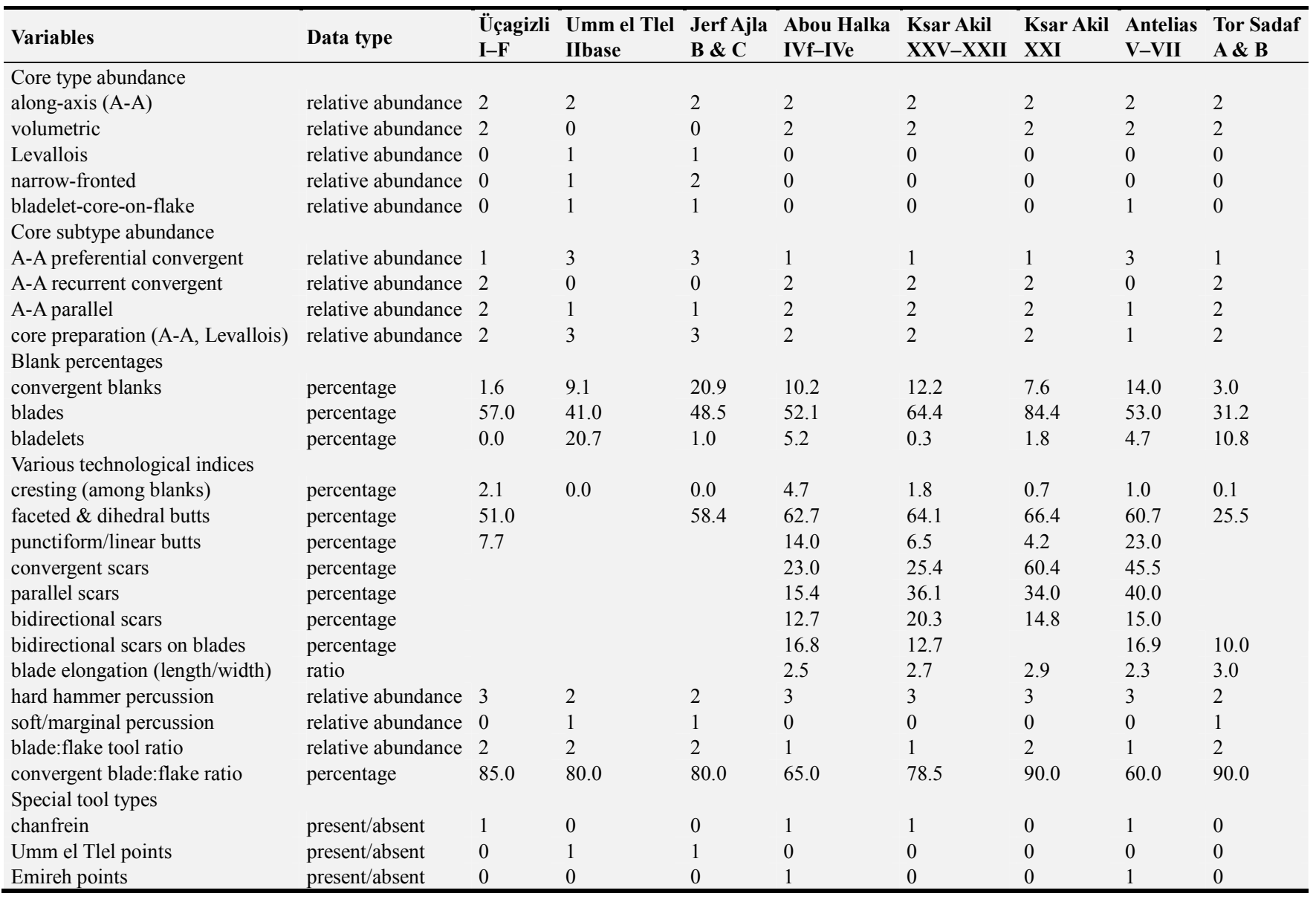


Table 2. Continued.

\begin{tabular}{|c|c|c|c|c|c|}
\hline Variables & Data type & Boker Tachtit 1 & Boker Tachtit 2-3 & Boker Tachtit 4 & Ansab 2 \\
\hline \multicolumn{6}{|l|}{ Core type abundance } \\
\hline along-axis $(\mathrm{A}-\mathrm{A})$ & relative abundance & 3 & 3 & 0 & 0 \\
\hline volumetric & relative abundance & 1 & 1 & 3 & 3 \\
\hline Levallois & relative abundance & 0 & 0 & 0 & 0 \\
\hline narrow-fronted & relative abundance & 0 & 0 & 0 & 0 \\
\hline bladelet-core-on-flake & relative abundance & 0 & 1 & 0 & 0 \\
\hline \multicolumn{6}{|l|}{ Core subtype abundance } \\
\hline A-A recurrent convergent & relative abundance & 0 & 0 & 0 & 0 \\
\hline A-A parallel & relative abundance & 1 & 2 & 0 & 0 \\
\hline core preparation (A-A, Levallois) & relative abundance & 1 & 1 & 0 & 0 \\
\hline \multicolumn{6}{|l|}{ Blank percentages } \\
\hline convergent blanks & percentage & 0.9 & 0.6 & 2.0 & 1.9 \\
\hline blades & percentage & 33.2 & 37.1 & 52.4 & 62.8 \\
\hline bladelets & percentage & & & & 6.5 \\
\hline cresting (among blanks) & percentage & 3.2 & 3.7 & 1.3 & 0.1 \\
\hline faceted \& dihedral butts & percentage & 42.1 & 47.1 & 40.2 & 35.4 \\
\hline punctiform/linear butts & percentage & & & & 6.7 \\
\hline convergent scars & percentage & & & & 47.4 \\
\hline parallel scars & percentage & & & & 33.3 \\
\hline bidirectional scars & percentage & 39.8 & 38.0 & 19.7 & 6.4 \\
\hline bidirectional scars on blades & percentage & 50.9 & 46.5 & 17.1 & 7.0 \\
\hline blade elongation (length/width) & ratio & 2.6 & 2.5 & 2.5 & 2.7 \\
\hline hard hammer percussion & relative abundance & 3 & 3 & 3 & 3 \\
\hline soft/marginal percussion & relative abundance & 0 & 0 & 0 & 0 \\
\hline blade:flake tool ratio & relative abundance & 2 & 1 & 2 & 2 \\
\hline convergent blade:flake ratio & percentage & 68.6 & 77.6 & 66.7 & 66.7 \\
\hline \multicolumn{6}{|l|}{ Special tool types } \\
\hline chanfrein & present/absent & 0 & 0 & 0 & 0 \\
\hline Umm el Tlel points & present/absent & 1 & 1 & 0 & 0 \\
\hline Emireh points & present/absent & 1 & 1 & 0 & 0 \\
\hline
\end{tabular}

Table 3. Palaeogeography data of the various IUP sites employed in PCA \& LDA.

\begin{tabular}{|c|c|c|c|c|c|c|}
\hline Assemblages & Proximity to water & Fauna & Biome & $\begin{array}{l}\text { Proximity to primary } \\
\text { raw material }\end{array}$ & $\begin{array}{l}\text { Proximity to secondary } \\
\text { raw material }\end{array}$ & Site type \\
\hline Üçagizli I-F & 1 & 1 & 1 & 0 & 1 & 1 \\
\hline Umm el Tlel IIbase & 1 & & 2 & 1 & 0 & 3 \\
\hline Jerf Ajla B \& C & 1 & 2 & 2 & 1 & 0 & 1 \\
\hline Abou Halka IVf-IVe & 1 & 1 & 1 & 0 & 1 & 2 \\
\hline Ksar Akil XXV-XXII & 1 & 1 & 1 & 1 & 1 & 2 \\
\hline Ksar Akil XXI & 1 & 1 & 1 & 1 & 1 & 2 \\
\hline Antelias V-VII & 1 & 1 & 1 & 1 & 1 & 1 \\
\hline Tor Sadaf A \& B & 1 & 3 & 2 & 0 & 1 & 2 \\
\hline Boker Tachtit 1 & 1 & & 2 & 1 & 1 & 3 \\
\hline Boker Tachtit 2-3 & 1 & & 2 & 1 & 1 & 3 \\
\hline Boker Tachtit 4 & 1 & & 2 & 1 & 1 & 3 \\
\hline Ansab 2 & 1 & & 2 & 1 & 1 & 3 \\
\hline
\end{tabular}

Proximity to water: $1=<1 \mathrm{~km}$ distance, $0=>1 \mathrm{~km}$ distance; fauna: $1=$ cervids, boar, goat, $2=$ gazelle, wild ass, $3=$ gazelle, hare, tortoise; biome: $1=$ Mediterranean, $2=$ semi-arid; proximity to primary $/$ secondary raw material: $1=<5 \mathrm{~km}$ distance, $0=>5 \mathrm{~km}$ distance; site type: $1=$ cave, $2=$ rock shelter, $3=$ open-air

Table 4. Techno-economy data of the various IUP sites employed in PCA \& LDA.

\begin{tabular}{|c|c|c|c|c|c|c|c|c|c|}
\hline Assemblages & $\begin{array}{l}\text { points/ } \\
\text { backed } \\
\text { pieces }\end{array}$ & $\begin{array}{l}\text { endscrapers } \\
\text { chanfreins } \\
\text { truncations }\end{array}$ & $\begin{array}{l}\text { other tool } \\
\text { types }\end{array}$ & $\begin{array}{l}\text { tool kit } \\
\text { richness }\end{array}$ & $\begin{array}{l}\text { tool kit } \\
\text { evenness }\end{array}$ & $\begin{array}{l}\text { blank: core } \\
\text { ratio }\end{array}$ & $\begin{array}{l}\text { blank: tool } \\
\text { ratio }\end{array}$ & $\begin{array}{l}\text { tool: core } \\
\text { ratio }\end{array}$ & site function \\
\hline Üçagizli I-F & 5.53 & 37.4 & 57.07 & 0.3326 & 2.013 & \multirow[t]{2}{*}{29.9} & 3.7 & 8.2 & 1 \\
\hline Umm el Tlel IIbase & 65.22 & 8.7 & 26.09 & 0.5934 & 1.648 & & 7.3 & & 2 \\
\hline Jerf Ajla B \& C & 22.36 & 16.15 & 61.49 & 0.8669 & 2.194 & \multirow[t]{5}{*}{13.6} & 4 & 3.4 & 1 \\
\hline Abou Halka IVf-IVe & 10.48 & 44.34 & 45.17 & 0.6871 & 2.17 & & & 3.5 & 1 \\
\hline Ksar Akil XXV-XXII & 17.65 & 46.92 & 35.43 & 0.2468 & 1.973 & & & 6.6 & 1 \\
\hline Ksar Akil XXI & 6.61 & 43.92 & 49.47 & 0.386 & 1.686 & & & 4.5 & 1 \\
\hline Antelias V-VII & 24.13 & 45.45 & 30.42 & 0.7096 & 1.935 & & & 16.8 & 1 \\
\hline
\end{tabular}




\begin{tabular}{|c|c|c|c|c|c|c|c|c|c|}
\hline Assemblages & $\begin{array}{l}\text { points/ } \\
\text { backed } \\
\text { pieces }\end{array}$ & $\begin{array}{l}\text { endscrapers } \\
\text { chanfreins } \\
\text { truncations }\end{array}$ & $\begin{array}{l}\text { other tool } \\
\text { types }\end{array}$ & $\begin{array}{l}\text { tool kit } \\
\text { richness }\end{array}$ & $\begin{array}{l}\text { tool kit } \\
\text { evenness }\end{array}$ & $\begin{array}{l}\text { blank: core } \\
\text { ratio }\end{array}$ & $\begin{array}{l}\text { blank: tool } \\
\text { ratio }\end{array}$ & $\begin{array}{l}\text { tool: core } \\
\text { ratio }\end{array}$ & site function \\
\hline Tor Sadaf A \& B & 43.65 & 16.41 & 39.94 & 0.2782 & 1.211 & 42.1 & 14.2 & 3 & 2 \\
\hline Boker Tachtit 1 & 48.31 & 11.24 & 40.45 & 0.954 & 1.639 & 62.8 & 40.9 & 1.5 & 3 \\
\hline Boker Tachtit 2-3 & 29.2 & 11.68 & 59.12 & 0.6645 & 1.941 & 40.4 & 33.9 & 1.2 & 3 \\
\hline Boker Tachtit 4 & 39.9 & 26.94 & 33.16 & 0.5759 & 1.603 & 72.4 & 19.5 & 3.7 & 3 \\
\hline Ansab 2 & 34.21 & 31.58 & 34.21 & 0.9733 & 1.614 & 14.4 & 18.2 & 0.8 & 3 \\
\hline
\end{tabular}

Points/backed pieces represent hunting/ cutting activities; endscrapers, chanfreins \& truncations represent hide working activities; other tool types represent tool maintenance activities; site function: $1=$ residential site (broad spectrum of activities), $2=$ hunting/butchering + maintenance, $3=$ hunting/butchering + tool maintenance + workshop

\subsection{Techno-Typological Variables}

As not every reader might be familiar with all technotypological variables mentioned in this study, they are briefly outlined in following (Table 2; Figure 3). For more detailed accounts, the reader is referred to the primary literature however (Table 1).

The first block in Table 2 entails the major core concepts characterising the IUP. The most commonly shared concept is represented by along-axis cores (A-A cores), i.e. hierarchically organised cores with an upper exploitation surface opposite to a lower preparation/ maintenance surface (Figure 3 (1-3)). Some authors subsume A-A cores under Levallois cores, while others set them apart due to more volumetric configurations and lack of centripetal preparation [52, 53, 4, 38, 43]. Typical Levallois cores on the other hand are rare, and were mostly found in Syria [31-34].

Volumetric narrow-fronted cores bear a single exploitation surface used for the production of narrow blade/lets. The exploitation surface was located at the narrow front of the raw nodule $[31-34,54]$. In some IUP sites flakes and/or blades were used as cores for the production of bladelets ([34, 39]. These are referred to as bladelet-core-on-flakes here (Figure 3 (7)).

In the next block, A-A cores are subdivided in three groups. The goal of A-A preferential convergent cores was the production of a single convergent blank per reduction sequence (Figure 3 (1)), whereas the production of convergent blanks in A-A recurrent convergent cores was embedded in a continuous blade reduction process (Figure 3 (2); [4, 38, 43]. Furthermore, parallel-sided blades were produced on parallel A-A cores (Figure $3(3)$; $[38,43]$ ). The variables employed in the next two blocks are commonalities in Palaeolithic research that should not need further explaining.

The three tool types in the final block can be found in some assemblages, but not in others. An oblique burin scar placed at the distal end of an endscraper defines chamfered pieces, also called chanfreins (Figure 3 (17-18); [22]). This chamfering technique is thought to have aimed for resharpening endscrapers, however, use-wear studies remain to be carried to confirm this [55]. Chanfreins were discovered in abundance from Lebanese IUP sites, while few specimens have been reported from Üçağızli Cave $[30,55]$.

Umm-el Tlel points are characterised by the thinning of their dorsal-proximal part via convergent bladelets (Figure 3 (16); $[32,40])$. These bladelets were removed just before the point was detached from its core. Umm-el Tlel points were reported from Central Syria and from Boker Tachtit in the southern Negev Desert.

Emireh points are elongated, triangular blanks, mostly of blade proportions, that are characterised by proximal thinning on both the dorsal and the ventral side (Figure 3 (15); [39, 46]. Emireh points were found in Lebanon and at Boker Tachtit abundantly. Basal thinning in both point types is thought to have facilitated hafting in organic shafts.

\section{Results}

\subsection{Techno-Typological Variability of the Levantine IUP}

The first principal component related to technological variability $(\mathrm{PC} 1=44.35 \%)$ is made up of the various scar patterns, the relative abundance of Levallois, narrow-fronted, bladelet-core-on-flake and A-A preferential convergent cores respectively, as well as, the application of the soft hammer/marginal percussion technique and the presence/absence of Umm el Tlel points (Table 5). Therefore, PC1 sets apart the assemblages of Umm el Tlel and Jerf Ajla in Central Syria.

The second principal component $(\mathrm{PC} 2=19.56 \%)$ includes A-A core and bladelet-core-on-flake abundances, cresting and linear/punctiform butt percentages, as well as, the presence/absence of Emireh points. PC2 sets apart the early levels of Boker Tachtit (levels 1-3) in the Negev Desert and the Antelias Cave in the Mediterranean zone in Lebanon.

The third principal component $(\mathrm{PC} 3=14.49 \%)$ revolves around the relative abundance of recurrent convergent A-A cores, the core preparation techniques applied to hierarchical cores, the percentage of convergent blanks and of faceted and dihedral butts, plus the presence/absence of chanfreins. Thus, PC3 separates assemblages from Üçagizli, Abou Halka, Ksar Akil, located in the current Mediterranean biome from the southern open-air assemblages of Tor Sadaf, Boker Tachtit 4 and Ansab 2, located in the current semi-arid zone. 
Table 5. Results of the PCA for techno-typology, palaeogeography and techno-economy data of Levantine IUP assemblages.

\begin{tabular}{|c|c|c|c|}
\hline PC & Eigenvalue & $\%$ variance & Attributes \\
\hline \multicolumn{4}{|c|}{ Techno-typology } \\
\hline 1 & 11.9746 & 44.35 & all scar patterns, Levallois, $\mathrm{N}$-fronted, bladelet-core-on-flake, Mode A, marginal percussion, Umm el Tlel pts. \\
\hline 2 & 5.28049 & 19.557 & AA-cores, Mode A, bladelet-core-on-flake, Icr, pct/lin butts, Emireh points \\
\hline 3 & 3.9113 & 14.486 & Mode B, AA-prep, IF, convergent blanks, chanfrein \\
\hline \multicolumn{4}{|c|}{ Palaeogeography } \\
\hline 1 & 2.95206 & 59.041 & biome, fauna, site type \\
\hline 2 & 1.07061 & 21.412 & proximity to secondary raw material \\
\hline 3 & 0.770454 & 15.409 & proximity to primary \& secondary raw material \\
\hline \multicolumn{4}{|c|}{ Techno-economy } \\
\hline 1 & 4.22937 & 46.993 & site function, points, blank:tool ratio \\
\hline 2 & 2.19304 & 24.367 & other tools \\
\hline 3 & 1.04779 & 11.642 & tool richness, tool evenness, tool:core ratio \\
\hline
\end{tabular}

Preliminary groupings observed in PCA are substantiated by LDA supporting the determination of four groups (Figure 4). Group A contains the assemblages from Üçagizli, Abou Halka, Ksar Akil and Tor Sadaf that are characterised by convergent blank production from recurrent convergent A-A cores, and, blade production from volumetric cores respectively.

Group B entails the earlier assemblages of Boker Tachtit 1-3 and Antelias V-VII characterised by convergent blank production from preferential convergent A-A cores, as well as, by blade production from parallel A-A cores and from volumetric cores alike. Some flakes and blades were used for a designated bladelet production.

Group C contains the late assemblage of Boker Tachtit 4 and Ansab 2. Blade production was achieved by unidirectional, direct hard hammer percussion on volumetric cores. While convergent blanks appear to be present in these assemblages, they represent a mere by-product of convergent core exploitation on volumetric cores [40].

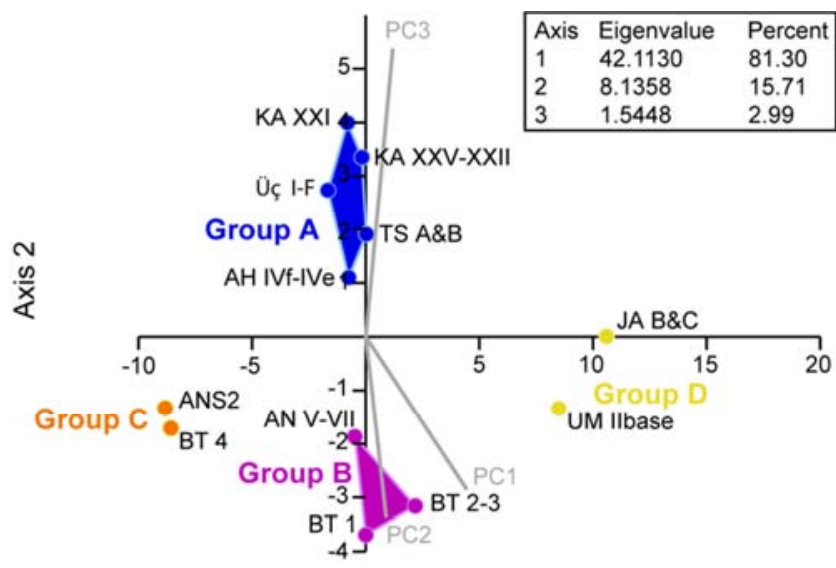

Axis 1

Figure 4. Results of the LDA based on technological data.

\subsection{Palaeogeographic Variability of the Levantine IUP}

Although, information on palaeogeographic aspects of IUP sites is limited, a brief overview can be found below (Table 3). Sites in the current Mediterranean zone are either caves (Antelias, Üçağızli) or rock shelters (Ksar Akil, Abou Halka), while those in the semi-arid zone are mainly open-air sites (Boker Tachtit, Ansab 2, Umm el Tlel) plus one cave (Jerf
Ajla) and one rock shelter (Tor Sadaf; Figure 1). All Mediterranean sites are located near wadis [22, 26, 27, 30]. Contrastingly, sites in the current semi-arid biome are found near palaeo water streams, lakes, or marshes indicating improved climate conditions during their time of occupation [35-37, 56, 57].

The faunal records of the Mediterranean sites are composed of Dama mesopotamica, Capra aegragrus, Capreolus capreolus, and Sus scrofa pointing towards woodland and rugged, hilly terrain at their time of occupation $[20,22,30,58]$. There is also evidence of small-game hunting and shellfish consumption [19, 20]. Faunal records from the present semi-arid biome are sparse. At Tor Sadaf, consumption of Gazella gazella, lepus sp. and testudo sp. confirms the past semi-arid biome and proximity to marshy wetlands [35]. No faunal remains survived in Boker Tachtit, but pollen data suggests slightly wetter conditions than today [59]. Preliminary studies from Jerf Ajla and Umm el Tlel suggest exploitation mainly of Gazella gazella and various Equidae [56, 57]. This might be transferrable to other sites in the semi-arid zone where faunal remains either are absent, or have not been published yet.

Considering raw material availability, all IUP sites were placed in close proximity to raw material sources. Prehistoric people in Üçağıli Cave exploited two secondary sources within a $5 \mathrm{~km}$ radius, while primary Cretaceous and Tertiary sources, located 20-30 km away, were exploited to a lesser extent [30]. Lithics from nearby secondary sources represent the complete chaine opératoire, whereas distant sources are represented by imported blanks and tools only. Similarly, a range of flint raw materials originating from various primary sources were used in Lebanon, but nodules from adjacent wadis had been exploited too [4, 60]. At Boker Tachtit, people used good-quality Eocene flint from a nearby limestone cliff, and secondary nodules were used from the adjacent wadi [36, 61]. Stone knappers in Jerf Ajla C primarily used local, good-quality Eocene flint (ca. 90\%) and to a lesser extent Cretaceous sources that were some 10-12 $\mathrm{km}$ away [62]. Although studies are currently in a preliminary stage, a similar pattern emerges from Umm elTlel III2b-IIbase [57]. Ansab 2 is located at an Eocene flint outcrop with good to mediocre (cracked) flint blocks and round nodules; both were used in abundance [37].

The first principal component related to palaeogeographic 
variability $(\mathrm{PC} 1=59.04)$ is comprised of the biome, fauna and site type differentiating Mediterranean from semi-arid assemblages (Table 5). Since the biome was partially reconstructed based on faunal data, a second PCA run without the biome was conducted resulting in the same groupings.

The second principal component $(\mathrm{PC} 2=21.41 \%$ ) revolves around proximity to secondary raw material sources that differentiates Central Syrian sites from southern Levantine ones. The third principal component $(\mathrm{PC} 3=15.41 \%)$ is constituted by the proximity to both primary \& secondary raw materials.

Preliminary groupings that were already indicated by PCA could be confirmed by LDA, supporting the determination of three groups (Figure 5). Group A contains assemblages from Üçagizli, Abou Halka, Ksar Akil and Antelias, all of which belong to the Mediterranean biome.

Group B is comprised of the Central Syrian sites, Jerf Ajla and Umm el Tlel located in the semi-arid biome. Both are positioned relatively far from secondary raw materials sources. They also yielded the youngest radiometric dates of all IUP sites under study (Figure 2).

Group C entails the southern semi-arid sites that are positioned near both, primary and secondary flint sources (Boker Tachtit, Ansab 2), with the exception of Tor Sadaf. Close proximity to fresh water and flint sources seem to have been critical factors for site selection among Levantine IUP communities, which likely was the case in respect to vital food resources too.

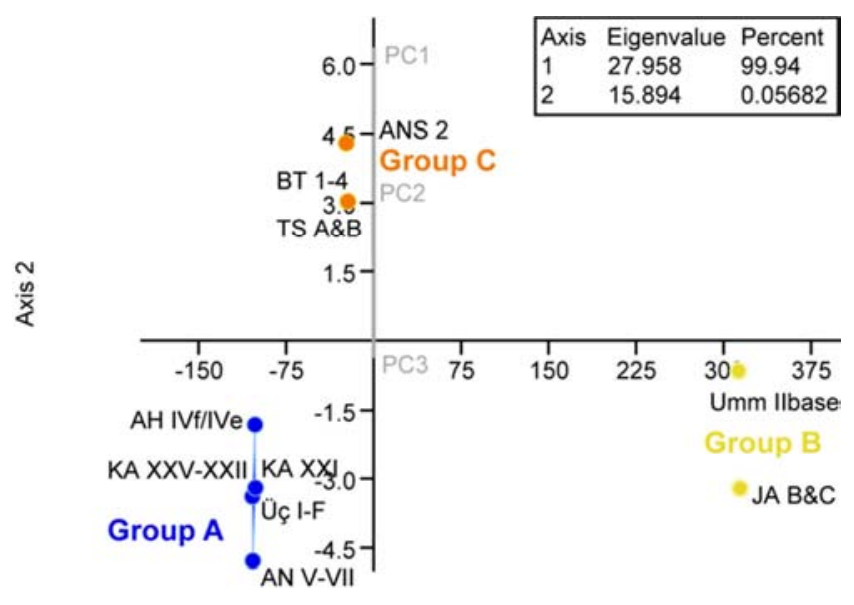

Axis 1

Figure 5. Results of the LDA based on palaeogeography data.

\subsection{Techno-Economical Variability of the Levantine IUP}

In order to investigate techno-economic patterns of the various Levantine IUP sites, a number of proxies were considered (Table 4). Tool types were grouped according to their presumed functions. The various point types should represent hunting/butchering activities analogues to Levallois points [45]. Points are more abundant in the semi-arid zone, particularly in Umm el Tlel. Mediterranean assemblages on the other hand are rich in endscrapers, chanfreins and truncations, reflecting hide and skin processing activities. The group 'other tools' reflects a broad range of tool maintenance activities, resulting in no apparent clustering.

Tool kit richness is a reflection of the activity range performed with each assemblage (more tool types = richer), while tool kit evenness reflects functional specialisation (more tools of one type = less even, more specialised; [63]). Mediterranean rock shelter sites yielded low richness values $($ mean $=0.3)$ as opposed to semi-arid open-air sites (mean $=$ 0.8 ); cave sites assume an intermediate position. This is indicative of a broad activity range carried out in the semiarid zone despite relatively small tool kits. Tool kit evenness is higher among assemblages from the Mediterranean biome $($ mean $=2.0)$ as opposed to those from the semi-arid biome $($ mean $=1.7)$, showing more specialised activities among the latter (hunting/butchering).

Blank:core ratios indicate on-site blank production and are expected to be higher at workshop sites, but they can also reflect import/export of blanks and cores. Blank:core ratios could not be calculated for sites excavated around WWII as not all blanks were retained in contrast to e.g. cores and tools [22, 23]. As expected, assemblages from Boker Tachtit display high blank:core ratios that together with abundant artefact refits and low tool numbers confirm its workshop character $($ mean $=58.3: 1)$. The low blank:core ratio at the workshop site, Ansab 2, can only be explained by blank export (14:1). Judging from artefact refits, 30-40 blanks per core should be expected. Blank:core ratios of the other assemblages assume intermediate positions.

Blank:tool ratios show the frequency of blanks being transformed into tools, serving as a means to estimate the duration of site occupation. Therefore, during long-term occupations more blanks were transformed into tools, resulting in low blank:tool ratios and vice versa. As expected, blank:tool ratios at southern Levantine open-air sites are quiet high (mean $=28.1: 1$ ) supporting the notion of shortterm occupations combined with on-site blank production (e.g. [62]). In contrast, cave sites (Üçagizli and Jerf Ajla) produced low blank:tool ratios (mean $=3.9: 1)$ that agree with expectations of long-term occupations. Umm el Tlel assumes an intermediate position (7.3:1), partly due to its point abundance $(65.2 \%)$.

In the absence of reliable blank percentages from preWWII sites, tool:core ratios were calculated as an approximate measure of on-site production, assuming tool:core ratios to be low at primary production sites (workshops), and high at long-term residential sites (base camps). As expected, tool:core ratios are high in the Mediterranean biome (7.9:1 or 5.7:1 excluding AN VII-V) in contrast to the semi-arid biome (2.3:1) and semi-arid open-air sites in particular (1.8:1), confirming the residential character of Mediterranean sites. Furthermore, cave sites display the highest tool:core ratios (9.5:1 or 5.8:1 excluding AN VII-V) in comparison to open-air sites $(1.8: 1)$ while rock shelters assume an intermediate position (4.4:1) supporting the argument that caves and rock shelters were used for longterm occupations. 
The first principal component related to techno-economic variability ( $\mathrm{PC} 1=46.99 \%$ ) is comprised of the variables, site function, points and the blank:tool ratio, setting apart residential sites from those with more specialised activities (Table 5). The first group overlaps with the Mediterranean biome except for the only cave site in the semi-arid region, Jerf Ajla. As site function was partially based on data compiled in Table 4, a second PCA run without site function was performed, resulting in the same groupings. The second principal component $(\mathrm{PC} 2=24.38 \%)$ revolves around 'other tools', which sets apart Boker Tachtit 2-3 and Jerf Ajla B\&C. The third principal component $(\mathrm{PC} 3=11.64 \%)$ entails tool kit richness, tool kit evenness and the tool:core ratio, resulting in no clear patterning.

These partially contrasting group constellations were further investigated by performing a LDA, whose results support the notion of three techno-economic groups (Figure 6). Group A contains the assemblages from Üçagizli Cave, Abou Halka, Ksar Akil and Antelias Cave that belong to the Mediterranean biome plus Jerf Ajla Cave. These sites probably served as residential base camps where similar activities were carried out during each stay. Group B is comprised of Boker Tachtit 2-3 and Ansab 2, workshop sites with moderate numbers of hunting/butchering tools, but with abundant maintenance and/or hide and skin processing tools. Group $\mathrm{C}$ is similarly characterised by maintenance plus hunting/butchering activities and, in the case of Boker Tachtit 1 and 4 , by workshop activities blurring the boundary with Group B.

To sum up, residential sites display comparatively even tool distribution patterns and they overlap with the Mediterranean biome, with the only noteworthy exception being Jerf Ajla Cave in the semi-arid zone. Other sites in the semi-arid zone indicate more varied activities that revolve around hunting/butchering, workshop and tool maintenance activities. Their activity spectrum is essentially similar to the observed Mediterranean sites, but their activities tend to be more specialised.

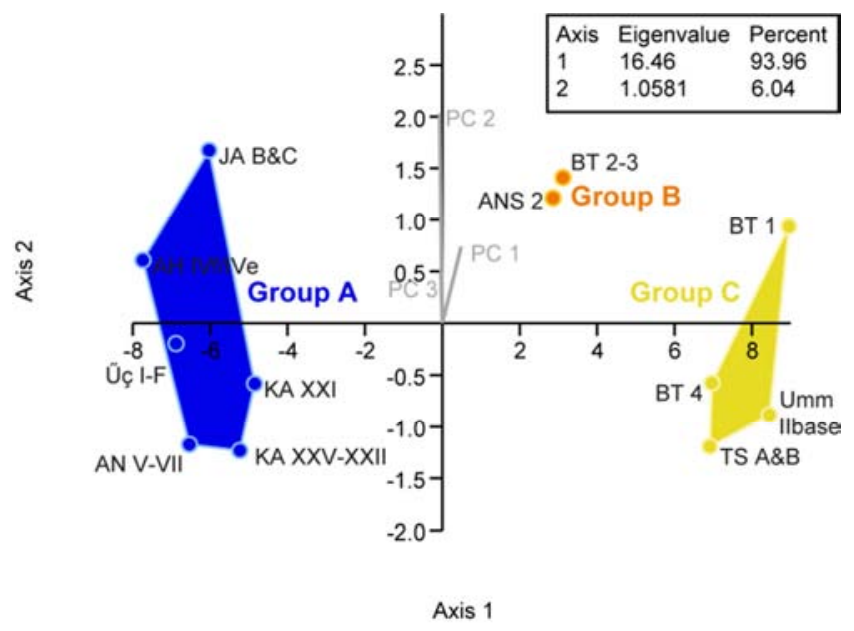

Figure 6. Results of the LDA based on techno-economic data.

\section{Discussion}

Considerable inter-assemblage variability among Levantine IUP lithic assemblages has been acknowledged for a long time now, thus, the aim of this study was to systematically investigate this techno-typological variability and to identify potentially undelaying factors related to palaeogeography and techno-economy.

The study indicates that group associations of Mediterranean sites are consistent across the three investigated categories; techno-typology, palaeogeography and techno-economy, with the single exception of Antelias Cave that is techno-typologically more similar to older assemblages from Boker Tachtit 1-3, located in the Negev Desert (Figure 7). Also, group associations among Central Syrian sites are quite consistent, only Jerf Ajla Cave displays techno-economical constellations that otherwise characterise Mediterranean sites.

Contrastingly, group associations of the southern Levantine assemblages fluctuate considerably; while they form a distinct cluster regarding palaeogeography, they only partially do so in respect to the other two categories. Concerning techno-typology, some of them are more similar to Mediterranean sites (Boker Tachtit 1-3; Tor Sadaf A\&B), while from a techno-economic perspective, some are more similar to the northern semi-arid ones (Boker Tachtit 1, 4; Tor Sadaf A\&B).

The results suggest that the techno-typological variability observed among all Levantine IUP assemblages neither solely depends on palaeogeography $(\mathrm{r}=0.41, \mathrm{p}=0.19)$, nor on techno-economic factors $(r=0.35, p=0.27)$. Regarding assemblages associated with the Mediterranean biome, the single most influential factor seems to be related to the biome itself (Figure 7), whereas techno-typological variability among assemblages associated with the semi-arid biome display a stronger dependence on techno-economic factors $(\mathrm{r}=-0.79, \mathrm{p}=0.36)$ rather than paleogeography $(\mathrm{r}=0.41, \mathrm{p}=$ $0.03)$.

While there is no doubt that paleogeography and behavioural economy had an impact on past human technotypology, some of the observed variability might also be related to cultural/social factors such as cultural transmission or diversification of material culture traditions with time $[4,9$, 64]. Figure 8 provides a tentative diachronic perspective, acknowledging the limitations resulting from the few dated sites, differing dating methods and the different materials dated. Some possible cultural/social factors that may have had an impact on the techno-typological variability of the Levantine IUP are discussed below.

Assemblages of the same TechGroups, such as TechGroups A \& B (Bokerian A-C) are found in both biomes, i.e. Mediterranean and the semi-arid biome, but display diverse techno-economic and paleogeographic patterns, which would not necessarily be expected in a stringent adaptive system.

Assemblages from the Antelias Cave are similar to those from the open-air site Boker Tachtit, displaying a 
standardised core reduction strategy (A-A preferential convergent), that otherwise constitutes but a minor component at the other assemblages in the Mediterranean zone (Ksar Akil, Abou Halka, Üçagizli). Among the latter, convergent blanks were produced via a more flexible core reduction strategy (A-A recurrent convergent), that is comparable to the Levallois recurrent convergent method of the preceding Late Middle Palaeolithic [4, 38, 43]. A possible scenario underlying the observed pattern might be a population of newcomers coming from the Negev to the Antelias Cave, who were equipped with a unique technotypological set, and who only later adopted and modified Late Middle Palaeolithic core reduction strategies. However, this will have to remain speculative for now, particularly in the absence of precise age estimates for both sites.

Similarly, the techno-typological association of the Tor Sadaf assemblages with those from the Mediterranean zone (TechGroupB, Bokerian B/C), finds no equivalent either in respect to adaptive behaviour patterns or to palaeogeography, yet, they seem to share similar material culture traditions.

TechGroup C (Boker Tachtit 4, Ansab 2) remains enigmatic due to imprecise dating or even absence of dating, henceforth, leaving room for speculation. Besides that, the sudden disappearance of A-A cores, in comparison to older Boker Tachtit assemblages, despite similar blank products, same site function and same palaeogeographic setting, makes adaptive strategies a less likely factor for explaining these shared technotypological attributes. If the temporal positon around $40 \mathrm{ka} \mathrm{cal}$ $\mathrm{BP}$ was correct, then this might imply a diachronic trend seen in long stratigraphic sequences all over the Levant (Ksar Akil, Üçagizli Boker Tachtit), when hierarchically organised core concepts became less frequent, while volumetric ones gained ground, ultimately, resulting in Early Upper Palaeolithic material culture traditions [5, 27-29, 30, 54].

The most distinctive assemblage cluster, the TechGroup D (Jerf Ajlan) in Central Syria, also provides the youngest age estimates of all IUP sites, and displays unique technotypological features. Dissimilar to other IUP assemblages, recurrent convergent cores (A-A cores or Levallois) were initiated by centripetal flakes rather than by along-axis blade removals or cresting. In addition, $\mathrm{N}$-fronted cores, that otherwise characterise contemporaneous Early Upper Palaeolithic assemblages, were employed for the production of bladelets [34, 54].

\section{Conclusion}

This study has forwarded three major findings concerning the Levantine IUP, a) there is considerable techno-typological inter-assemblage variability, b) techno-typological variability to some extent depends on paleogeography and technoeconomy and c) while assemblages in the Mediterranean zone are comparatively similar to each other, those in the semi-arid zone display much more variability regarding techno-typology and techno-economic behaviour.

Analogues to palaeoeconomic factors that had an impact on assemblage variability, and as was outlined throughout this paper, there is a need for a more thorough understanding of cultural/social factors that may have contributed to the lithic variability of the Levantine IUP. However, this must be left to future work for now.

Positioned at the cross-roads between Africa and Eurasia, the considerable variability of the Levantine IUP regarding techno-typology, palaeogeography and techno-economy evidenced in this study, conforms to previous arguments for regional and temporal diversity (Figure $8 ;[4,6]$ ). This bears implications for the Eurasian IUP in general, where analogues to the Levant, one should equally expect considerable variability that was likely conditioned by a multitude of factors, including adaptive behavioural strategies, different material culture traditions, and multiple human dispersals [10].
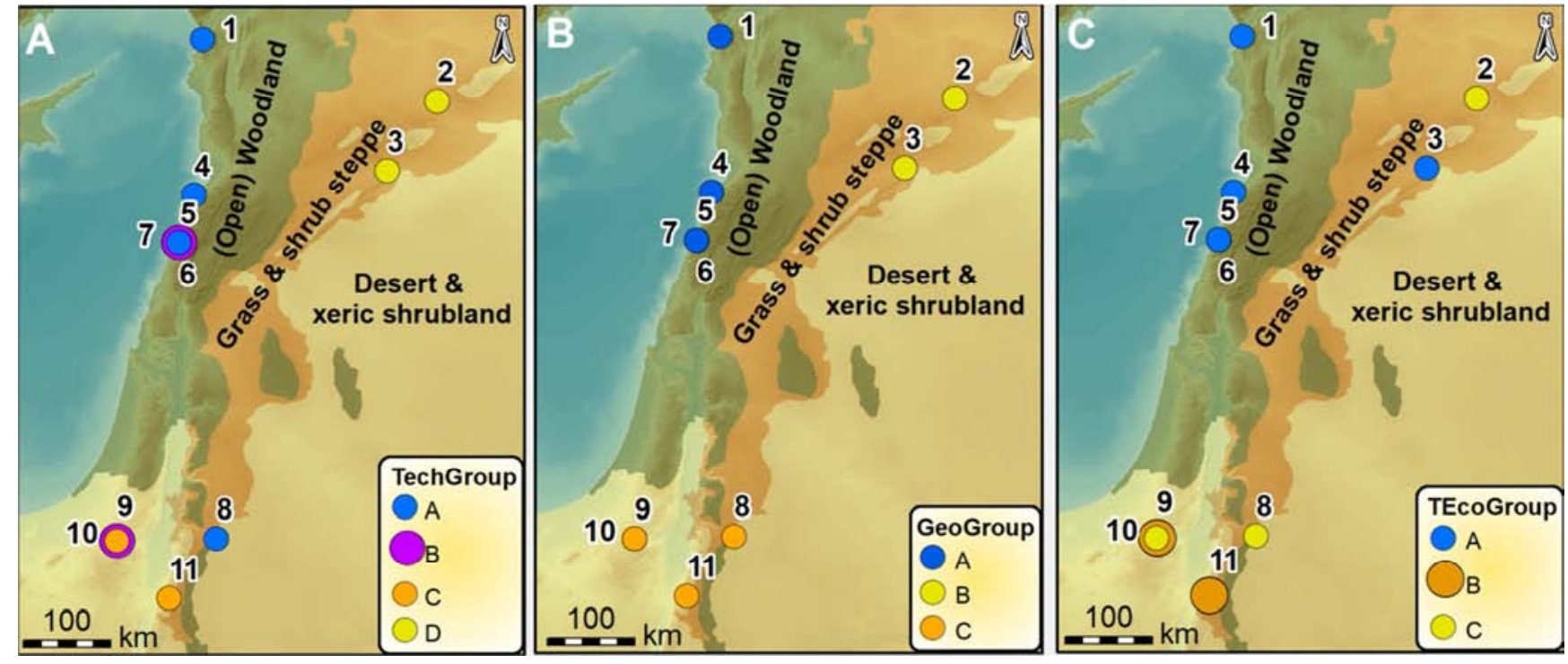

Figure 7. Maps of group clusters resulting from LDA. Note the differences between groups based on (A) Techno-typology, (B) Palaeogeography and (C) Techno-economy. (1) Üçağızli Cave. (2) Umm el Tlel. (3) Jerf Ajla Cave. (4) Abou Halka. (5) Ksar Akil XXV-XXII. (6) Ksar Akil XXI. (7) Antelias Cave. (8) Tor Sadaf. (9) Boker Tachtit 1-3. (10) Boker Tachtit 4. (11) Ansab 2. 


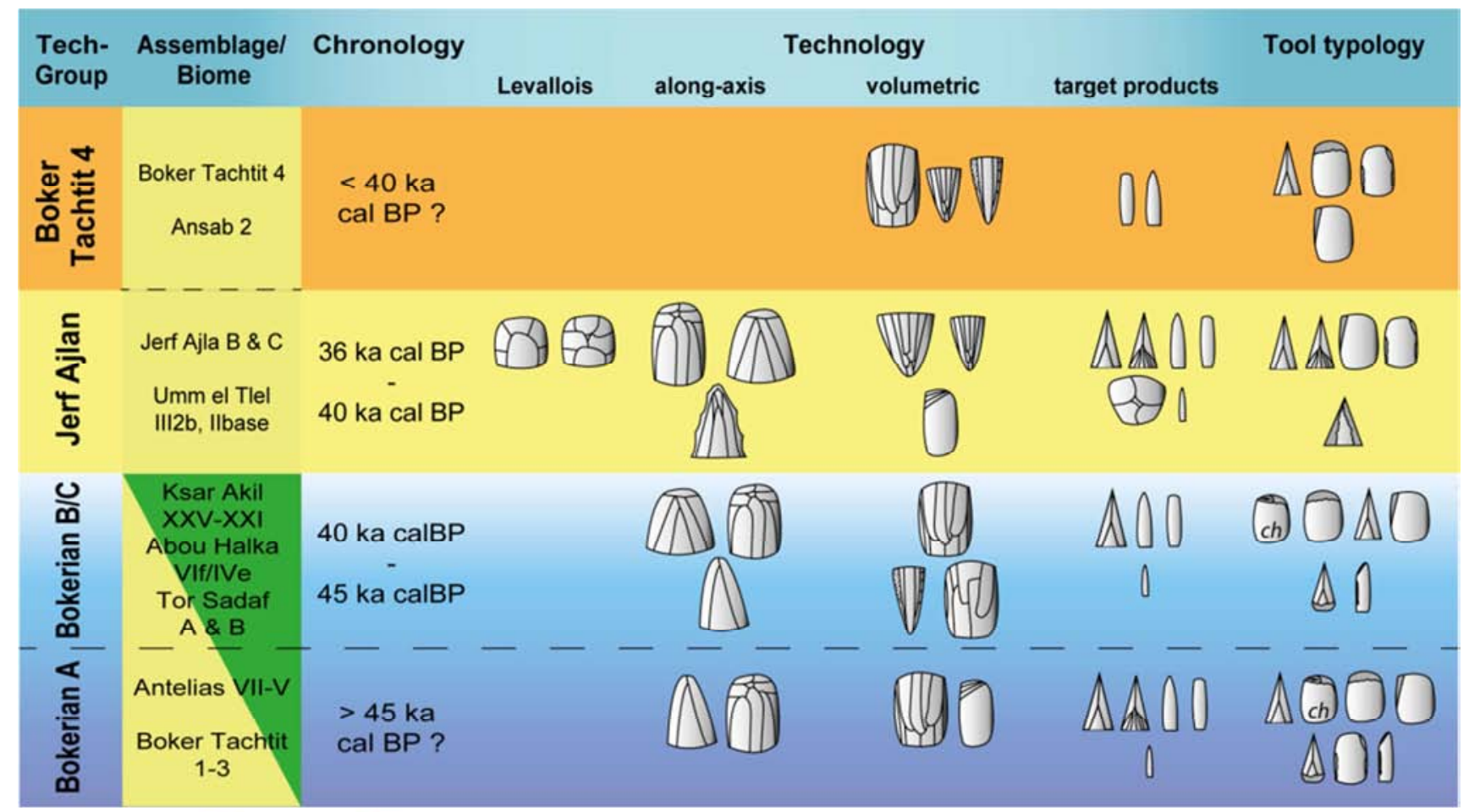

Biome: semi-arid $\square$ woodland $\square$

Cores: $\|_{\text {preferential convergent along-axis }}$ (semi-)pyramidal

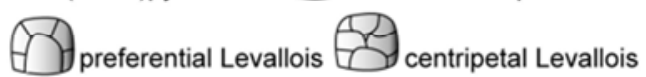

Blanks: 8 Levallois flakes $D_{\text {blunt blade }} A_{\text {pointed blade }} U_{\text {bladelet }} A_{\text {convergent blank }} \mathbb{A}_{\text {Umm el-Tlel point }}$

Tools: ch chanfrein $O_{\text {endscraper }} \Delta_{\text {convergent blank }} \bigcup_{\text {burin }} \Delta_{\text {Emireh point }} \bigcap_{\text {backed/pointed blank }} \bigcup_{\text {edge retouched piece }}$ Mousterian point

Figure 8. Techno-typological properties of the various TechGroups after Leder 2014 in regard to their regional and tentative chronological patterning.

\section{Acknowledgements}

I would like to express my gratitude to Jürgen Richter for his continuous support. I am indebted to Levon Nordiguian who granted access to collections of the Musée de Préhistoire Libanaise. I would also like to thank Nick Ashton who allowed me to study collections of Ksar Akil in the British Museum. Further thanks go to Stephanie Lovasz for access to Jean Haller's Abou Halka collections in the Museum der Kulturen Basel. Furthermore, I would like express my appreciation to Maya Haidar-Boustani, Debbie, Marie-Anne, Janet, and Nelly for their assistance with different Museum collections, as well as Thomas Hauck, Wei Chu, and Daniel Schyle for many stimulating discussions. Above all, I am most grateful to my wife, Laila Agassi, for her constant love and support.

\section{References}

[1] O. Bar-Yosef (2002). The Upper Palaeolithic revolution. Annual Review of Anthropology 31, 363-93.

[2] A. Belfer-Cohen and A. N. Goring-Morris, "The shift from the Middle Palaeolithic to the Upper Palaeolithic: Levantine perspective", in The Mediterranean from 50,000 to 25,000 BP: Turning points and new directions, M. Camps and C. Szmidt, Eds. Oxford: Oxbow Books, 2009. pp. 89-100.

[3] J. J. Hublin (2015). The modern human colonization of western Eurasia: when and where? Quaternary Science Reviews 118, 194-210.

[4] D. Leder, Technological and Typological change at the Middle to Upper Paleolithic boundary in Lebanon. Bonn: Universitätsforschungen zur prähistorischen Archäologie 255, 2014. 
[5] J. Rose and A. E. Marks (2014) "Out of Arabia" and the Middle-Upper Palaeolithic transition in the southern Levant. Quartär 61, 49-85.

[6] L. Meignen (2012). Levantine perspectives on the Middle to Upper Palaeolithic "Transition". Archaeology Ethnology \& Anthropology of Eurasia 40 (3), 12-21.

[7] H. S. Groucutt, M. D. Petraglia, G. Bailey, E. M. L. Scerri, A. Parton and L. Clark-Balzan (2015) Rethinking the dispersal of Homo sapiens out of Africa. Evolutionary Anthropology 24, 149-164.

[8] J. J. Shea (2008) Transitions or turnovers? Climatically-forced extinctions of Homo sapiens and Neanderthals in the east Mediterranean Levant. Quaternary Science Reviews 27, 2253-2270

[9] G. Tostevin, Seeing lithics: A middle-range theory for testing for cultural transmission in the Pleistocene. Oxford: Oxbow Books, 2012.

[10] S. L. Kuhn and N. Zwyns (2014) Rethinking the Initial Upper Paleolithic. Quaternary International 347, 29-38.

[11] M. Goder-Golberger, "Lithic variability along the Middle Paleolithic dispersal routes of modern humans 'Out of Africa'," unpublished Ph.D. thesis. Hebrew University of Jerusalem, 2014.

[12] J. Richter, T. Hauck, R. Vogelsang, T. Widlok, J. M. Le Tensorer and P. Schmid (2012) "Contextual areas" of early Homo sapiens and their significance for human dispersal from Africa into Eurasia between $200 \mathrm{ka}$ and $70 \mathrm{ka}$. Quaternary International 274, 5-24.

[13] A. Beyin (2011) Upper Pleistocene human dispersals out of Africa: A review of the current state of the debate. International Journal of Evolutionary Biology 2011, 1-17. doi: $10.4061 / 2011 / 615094$

[14] S. Oppenheimer (2012) A single southern exit of modern humans from Africa: Before or after Toba? Quaternary International 258, 88-99.

[15] A. Scally and R. Durbin (2012) Revising the human mutation rate: implications for understanding human evolution. Nature Reviews Genetics 13, 745-753.

[16] J. J. Hublin, A. Ben-Ncer, S. E. Bailey, S. E. Freidline, S. Neubauer and M. M. Skinner (2017) New fossils from Jebel Irhoud, Morocco and the pan-African origin of Homo sapiens. Nature 546, 289-292.

[17] I. Hershkovitz, G. W. Weber, R. Quam, M. Duval, R. Grün and L. Kinsley (2018) The earliest modern humans outside Africa. Science 359 (6374), 456-459.

[18] I. Hershkovitz, O. Marder, A. Ayalon, M. Bar-Matthews, G. Yasur and E. Boaretto (2015) Levantine cranium from Manot Cave (Israel) foreshadows the first European modern humans. Nature. 520, 216-219.

[19] S. L. Kuhn, M. Stiner, D. S. Reese and E. Güleç (2001) Ornaments of the earliest Upper Paleolithic: New insights from the Levant. Proceeding of the National Academy of Sciences 98 (13), 7641-7646.

[20] M. D. Bosch, M. A. Mannino, A. L. Prendergast, T. C. O'Connell, B. Demarchi and S. M. Taylor (2015) New chronology for Ksâr 'Akil (Lebanon) supports Levantine route of modern human dispersal into Europe. Proceeding of the National Academy of Sciences 112 (25), 7683-7688.

[21] F. Turville-Petre. Researches in prehistoric Galilee (1925-26). London, British School of Archaeology in Jerusalem, 1927.

[22] J. Haller (1946) Notes de préhistoire phénicienne: L'Abri de Abou-Halka (Tripoli). Bulletin de Musée de Beyrouth 6, 1-20.

[23] J. F. Ewing (1947) Preliminary note on the excavations at the Paleolithic site of Ksar' Akil, Republic of Lebanon. Antiquity 84, 186-196.

[24] D. A. E. Garrod (1951) A transitional industry from the base of the Upper Palaeolithic in Palestine and Syria. Journal of the Royal Anthropological Institute of Great Britain and Ireland $81,121-132$.

[25] D. A. E. Garrod (1955) The Mugharet el Emireh in Lower Galilee: Type station of the Emiran industry. Journal of the Royal Anthropological Institute of Great Britain and Ireland $85,143-161$.

[26] L. Copeland (1970) The Early Upper Palaeolithic flint material from Antelias Cave, Lebanon: Levels VII-V. Berytus $19,99-149$.

[27] I. Azoury I. Ksar Akil, Lebanon. Technological and typological analysis of the transitional and early Upper Palaeolithic levels of Ksar Akil and Abu Halka. Volume 1. Levels XXV-XII. Oxford, British Archaeological Reports, International Series 289, 1986.

[28] R. P. Iovita, "The Initial Upper Palaeolithic at Ksar Akil, Lebanon: A techno-typological analysis of Levels XXIV, XXI, XIX, and XVIII," unpublished B. A. thesis, Harvard University. 2001.

[29] K. Ohnuma, Ksar Akil, Lebanon: A technological study of the earlier Upper Palaeolithic levels of Ksar Akil. Volume 3. Levels XXV-XIV. Oxford, British Archaeological Reports, International Series 426, 1998.

[30] S. L. Kuhn, M. C. Stiner, E. Güleç, I. Özer, H. Yılmaz and I. Baykara (2009) The early Upper Paleolithic occupations at Üçağızlı Cave (Hatay, Turkey). Journal of Human Evolution $56,87-113$.

[31] B. Schroeder, "The lithic industries from Jerf 'Ajla and their bearing on the problem of a Middle to Upper Paleolithic transition," unpublished Ph.D. thesis, Columbia University New York, 1969.

[32] D. Richter, H. B. Schroeder, W. J. Rink, P. J. Julig and H. P. Schwarcz (2001) The Middle to Upper Paleolithic transition in the Levant and new thermoluminescence dates for a late Mousterian assemblage from Jerf al-Ajla Cave (Syria). Paléorient 27, 29-46.

[33] L. Bourguignon, "Les industries du Paléolithique intermédiaire d'Umm El-Tlel: Nouveaux éléments pour le passage entre Paléolithique moyen et supérieur," in Préhistoire d'Anatolie: Genèse de deux mondes, M. Otte, Ed. Liège: Actes du colloque international, Liège, 28 avril - 3 mai 1997, 1998, pp. 709-730.

[34] E. Boëda, S. Bonilauri, E. Kaltnecker, H. Valladas and H. AlSakhel (2015) Un débitage lamellaire au Proche-Orient vers 40000 ans cal BP. Le site d'Umm el Tlel, Syrie centrale. L'anthropologie 119, 141-169. 
[35] J. R. Fox, "The Tor Sadaf lithic assemblage: A technological study of the earliest Levantine Upper Palaeolithic in Wadi alHasa," in More than meets the eye: Studies on Upper Palaeolithic diversity in the Near East, A. N. Goring-Morris, A Belfer-Cohen, Eds. Oxford: Oxbow books, 2003, pp. 80-94.

[36] A. E. Marks, "The sites of Boker \& Boker Tachti: A brief introduction," in Prehistory and paleoenvironments in the Central Negev, Israel. Volume III: The Avdat/Aqev area, A. E. Marks, Ed. Dallas, Dallas Southern Methodist University Press, 1983, 15-37.

[37] D. Schyle, "The Upper Palaeolithic sequence of the Petra area and the Upper Palaeoloithic of the Levant," in Pleistocene Archaeology of the Petra Area in Jordan, D. Schyle and J. Richter, Eds. Rahden/Westfalen: Marie Leidorf, 2015, pp. 361-393.

[38] D. Leder (2016) Core reduction strategies at the Initial Upper Palaeolithic sites Ksar Akil and Abou Halka in Lebanon. Lithics: the Journal of the Lithic Studies Society 37, 33-54.

[39] A. E. Marks and D. Kaufman, "Boker Tachtit: The artifacts," in Prehistory and paleoenvironments in the Central Negev, Israel. Volume III: The Avdat/Aqev area, A. E. Marks, Ed. Dallas, Dallas Southern Methodist University Press, 1983, pp. 69-125.

[40] P. W. Volkman, "Boker Tachtit: Core reconstructions," in Prehistory and paleoenvironments in the Central Negev, Israel. Volume III: The Avdat/Aqev area, A. E. Marks, Ed. Dallas, Dallas Southern Methodist University Press, 1983, pp. 127190.

[41] K. Douka (2013) Exploring "the great wilderness of prehistory": The chronology of the Middle to the Upper Paleolithic transition in the Northern Levant. Mitteilungen der Gesellschaft für Urgeschichte 22, 11-40.

[42] D. M. Olson, E. Dinerstein, E. D. Wikramanayake, N. D. Burgess, G. V. N. Powell and E. C. Underwood (2001) Terrestrial ecoregions of the world: a new map of life on Earth. Bioscience 51 (11), 933-938.

[43] L. Meignen, O. Bar-Yosef, "Réflexions sur la fin du Paléolithique moyen et les débuts du Paléolithique supérieur au Proche-Orient," British Archaeological Reports, International series 1239,2004 , pp. 235-246 [Actes du XIV ${ }^{\circ}$ Congrès UISPP, Liège, 2001].

[44] J. Sarel, "The Middle-Upper Paleolithic transition in Israel," Oxford, British Archaeological Reports, International series $1229,2004$.

[45] M. L. Sisk and J. J. Shea (2011) The African origin of complex projectile technology: An analysis using tip crosssectional area and perimeter. International Journal of Evolutionary Biology 2011, Article ID 968012, 1-8. doi:10.4061/2011/968012.

[46] L. Copeland (2000) Forty-six Emireh points from the Lebanon in the context of the Middle to Upper Paleolithic transition in the Levant. Paléorient 26 (1), 73-92.

[47] O. Bar-Yosef and B. Vandermeersch, "The stratigraphical and cultural problems of the passage from Middle to Upper Paleolithic in Palestinian caves," in The origins of Homo sapiens, F. Bordes, Ed. Paris: UNESCO, 1972, pp. 221-225.

[48] O. Barzilai and N. Gubenko (2018) Rethinking Emireh Cave: The lithic technology perspectives. Quaternary International
464 (A), 92-105.

[49] S. Kadowaki (2017) Technology of striking platform preparation on lithic debitage from Wadi Aghar, southern Jordan, and its relevance to the Initial Upper Palaeolithic technology in the Levant. Al-Rāfidān, Journal of western Asiatic studies 38, 23- 32.

[50] A. J. Stutz, J. J. Shea, J. A. Rech, J. S. Pigati, J. Wilson and M. Belmaker (2015). Early Upper Paleolithic chronology in the Levant: new ABOx-SC accelerator mass spectrometry results from the Mughr el-Hamamah Site, Jordan. Journal of Human Evolution 85, 157-173.

[51] Ø. Hammer, D. A. T. Harper, P. D. Ryan (2001). PAST: Paleontological statistics software package for education and data analysis. Palaeontologia Electronica 4 (1), 1-9.

[52] E. Boëda, "Levallois: a volumetric construction, methods, technique," in The definition and interpretation of Levallois technology, H. L. Dibble and O. Bar-Yosef, Eds. Madison: Monographs in World Archaeolgy 23, 1995, pp. 41-69.

[53] L. Copeland (1983) Levallois/ non-Levallois determination in the Early Levantine Mousterian: Problems and questions for 1983. Paléorient 9 (2), 15-27.

[54] A. N. Goring-Morris and A. Davidzon (2006) Straight to the point: Upper Paleolithic Ahmarian lithic technology in the Levant. Anthropologie (Brno) 44 (1), 93-111.

[55] M. H. Newcomer (1969) The chamfered pieces from Ksar Akil (Lebanon). Bulletin of the Institute of Archaeology, London, 8-9, 1968-1969.

[56] B. Schroeder (2006) Shelter or hunting camp? Accounting for the presence of a deeply stratified cave site in the Syrian steppe. Near Eastern Archaeology 69 (2), 87-96.

[57] E. Boëda and S. Muhesen (1992) Umm El Tlel (El Kowm, Syrie): étude préliminaire des industries lithiques du Paléolithique moyen et supérieur 1991-1992. Cahiers de l'Euphrate 7, 47-92.

[58] D. A. Hooijer (1961) The fossil vertebrates of Ksâr 'Akil, a Palaeolithic rock shelter in the Lebanon. Zoologische Verhandelingen 49, 4-67.

[59] A. Horowitz. "Boker Tachtit and Boker: The pollen record," in Prehistory and paleoenvironments in the Central Negev, Israel. Volume III: The Avdat/Aqev area, A. E. Marks, Ed. Dallas, Dallas Southern Methodist University Press, 1983, pp. 63-68.

[60] C. Yazbeck, "The availability and Exploitation of raw materials in the Lower Paleolithic of Lebanon," in Chert availability and prehistoric exploitation in the Near East, C. Delage, Ed. Oxford: British Archaeological Reports, International series 1615, 2007, pp. 152-163.

[61] A. E. Marks, "The curation of stone tools during the Upper Pleistocene: A view from the Central Negev, Israel," in Upper Pleistocene prehistory of Western Eurasia, H. L. Dibble, A. Montet-White, Eds. Philadelphia: University Museum Press, 1988, pp. 87-94.

[62] P. J. Julig, D. F. G. Long, V. McFarland, B. Schroeder, "Sourcing of archaeological flints from the Middle to Upper Palaeolithic transition at Jerf Ajla Cave, Syria," in Chert availability and prehistoric exploitation in the Near East, C. Delage, Ed. Oxford: British Archaeological Reports, International series 1615, 2007, pp. 130-151. 
[63] M. J. Shott, S. Bowdler, C. J. Ellis, J. Francis, G. T. Jones and R. D. Leonard (1989) Diversity, organization, and behavior in the material record: Ethnographic and archaeological examples. Current Anthropology 30 (3), 283-315.
[64] S. L. Kuhn (2013) Questions of complexity and scale in explanations for cultural transitions in the Pleistocene: A case study from the Early Upper Paleolithic. Journal of Archaeological Method and Theory 20 (2), 194-211. 